https://jurnal.ugm.ac.id/rubikon

\title{
NETFLIX: CULTURAL DIVERSITY OR CULTURAL IMPERIALISM?
}

\author{
Khansa Salsabila \\ e-mail: khansasalsabila@mail.ugm.ac.id
}

\begin{abstract}
The global rise of Netflix as subscription video-on-demand (SVOD) has emerged along with its capitalization of film, television, and technology industry for the audience's convenience. It replaces the interest of local television with its claim of 'a global TV network' with cultural diversity in its contents. However, the term cultural diversity itself should be questioned whether it means to leave the American cultural power or it is only to claim themselves as a global company where global identity is represented in their identity to attract a wider audience. By using transnational approach, this study finds the use of cultural diversity merely to fulfill the demand of the American audience, with several globalization consequences in Netflix Original series, especially in nonAmerican series. Those consequences are the homogenization in European-made Netflix series, where they appear to be fully Americanized with American lifestyle or American perspective, and heterogenization in Asian-made Netflix series with its collaboration of Asian culture and American popular culture. The claim of a 'global TV network' itself does not leave the American cultural power. Instead, they are taking advantage of the cultural power to retain the existing audiences and to fascinate more audiences. Therefore, the dependency of non-American producers in relying on Netflix platform as a way to reach global audience, even the use of Americanization to their works for global audience's satisfaction, confirms the cultural power of America in its ability to bring economic advancement to other countries.
\end{abstract}

Keywords: cultural imperialism; globalization; heterogenization; homogenization; Netflix

DOI $\quad$ : https://doi.org/10.22146/rubikon.v8i1.65480

Available at https://jurnal.ugm.ac.id/rubikon/article/view/65480

This work is licensed under a Creative Commons Attribution-ShareAlike 4.0 International License

\section{INTRODUCTION}

The twenty-first century has been marked for its fast-growing technology for the
Article information

Received: 26 January 2021

Revised: 09 February 2021

Accepted: 23 February 2021 
contemporary social life based on the domination of power in reaching different types of societies (Rossi, 2007). This is unexceptionally for movies as the cultural product being accessed through the internet. The development of movies has been growing rapidly in which subscription video-ondemand (SVOD) emerged to fulfill people's need to unlimitedly watch ad-free movies anytime and everywhere during their free times only with a monthly charge, and this makes use of technology that has been developed earlier - phones, laptops, tablets, smart TV, along with the internet connection. In the last decade, there have been many in SVOD replacing the role of national television for its convenience and more options with freedom in watching their choice of movies. Many brands of this service have been known, such as Amazon Prime Video, Disney+, and Netflix. For several recent years, Netflix itself has positioned itself with its worldwide popularity and reputation as the largest SVOD provider who constantly offers the users highquality movies and series through their very own production of Netflix Originals. Netflix was, at first, an online DVD-rental service company founded in 1998, but it was not until 2012 when it started to release its own inhouse production of Netflix Original, such as House of Cards (2013-2015), Orange is the New Black (2013-2019), taking a prominent powerful role to re-define the term "television" while it was unconnected with large corporations that are dominating the global media, and indeed, this step challenges those corporations as they are able to quickly expand themselves to the global market (Jenner, 2018). With its sudden expansion to 130 countries at once in 2016 and currently is available for 190 countries all across the globe, Netflix has led the capitalization of the film, television, and technology industry with its innovative development and it has been praised as the future of television, while sometimes is also seen as a threat to the previous industry (Buck, \& Plothe, 2019).

Despite its capitalization to 190 countries, it has operated under different circumstances in each country (Jenner, 2018). The content Netflix provides in EU policies requires 30\% percent of its content to be European, while Poland itself requires $20 \%$ of Netflix content broadcasted in the country to be Polish, forcing the company to adopt the local culture and content while it is also an alternative way to avert cultural homogenization (Jenner, 2018). Indeed, the existence of Netflix as an online SVOD may replace the audience's interest in local national television, but it actually also tries to merge itself with the national television of many different countries to provide the local content and introduce them to its worldwide users, in other words, glocalization is being practiced in this matter. There have been many non-English movies or series produced and broadcasted by Netflix, such as La Casa de Papel or Money Heist (2017-) and Elite (2018-) from Spain, Kingdom (2019-) from South Korea, The Rain (2018-2020) from Denmark, Dark (20172020) from Germany. In the simplest way, it can be assumed that Netflix, despite its American-based company, does not put the American culture as the "main ingredient" for its products. However, such assumptions should be investigated further; while the company is under American neoliberalism and its laissez-faire, it cannot be denied that the American popular movies have been long globally consumed before Netflix gets in the game. Thus, the question comes up as if Netflix does produce its non-English product with local content to show the cultural 
diversity and to engage a wider cultural community as its audience, yet, because it is an American owned company, is there a way that with globalization, they are practicing the cultural imperialism, and perhaps, the Americanization of the local content? As quoted by CBS News, the CEO of Netflix, Reed Hasting announced, "You are witnessing the birth of a global TV network." Nevertheless, how do they employ the Americanization to claim themselves as a global company where global citizens are represented in their identity? What are their strategies to attract a more diverse audience from all cultural groups across the globe? This study investigated how cultural power has worked beneath the consciousness of the Netflix audience.

In seeing this phenomenon, this study will be conducted qualitatively and put the writer as the interpreter of Netflix Originals series. Articles and previous research regarding Netflix will also be used to support the analysis of the study. The collected data for this article will be limited to the popular series produced and provided by Netflix Original. Interpretation of Netflix Original series will be conducted by understanding the series and relating it to the cultural context within the approach. Hence, to have a deeper understanding, transnational approach to globalization will also be appropriately used in this study. This approach enables globalization theories concerning the cultural homogenization and heterogenization of Netflix Original. This includes putting more attention on the capitalist global system and the incomplete project of capitalist globalization (Sklair, 2007). The approach also focuses on a large scope of economy, politics, and culture-ideology that shape their characteristics as a dominant global system.
The transnational approach used in this study will focus more on the cultural-ideological sphere and try to put this study on the globalization debates over several categories which Sklair has listed; capitalism as the central issue of globalization, capitalist globalization that operates within the cultural imperialism of Westernization or Americanization, globalization that proposes homogenization and hybridization, and consumerism as the culture ideology. It also observes the tensed relationship of local and global in which cultural homogenization and heterogenization are the main issues, and thus hoped to acknowledge the differences of national culture in relation to power (Laemmerhirt, 2014). As it focuses on culture and is operated by the dominant power, the globalization theory on culture will be used to see and argue about the cultural imperialism produced by Netflix as an American company. It is also to provide a deeper understanding of the existence of local content produced within the activities of Netflix as the global dominant of SVOD service, as well as to trace the reason behind it.

In the context of culture ideology embedded in Netflix Originals series, the subchapter in this study will be divided into three subchapters in which it categorizes the series based on geographical and cultural division; America, Europe, and Asia. Netflix Originals series are analyzed by seeing the origin country and connecting it to the target audience in the global market using the transnational approach that previously has been explained. Such significant differences found in the three subchapters provide an answer to the idea of Americanization and cultural imperialism as asked previously. 


\section{DISCUSSION}

\section{Cultural Diversity for Culturally Diverse Society}

The internet allows the flow of globalization by the existence of digitalized cultural products such as books, music, pictures, news, movies, and many more to be shared and downloaded from all around the world (Ritzer, 2011). Nonetheless, it does not mean that culture flows easily and is accepted easily because of multiculturalism. In fact, there is also cultural differentialism in the process of globalization, along with cultural hybridization and cultural convergence. Cultural differentialism, as Ritzer explained, is the barrier that blocks the flow of homogenization of culture; it makes culture different from each other despite the rapid increase of technology to share cultural products.

America's multicultural society has struggled with its cultural differentiation in this global world. Netflix's attempt to neglect the typical American concept exemplifies how it makes use of the concept of cultural differentiation with Orange is the New Black (2013-2019) (Plothe \& Buck, 2019). This series breaks the typical American concept in which WASP characteristics are often employed as important roles. This evokes the increased participation of African-American actors, writers, directors, and producers to create a more diverse content that previously does not get more opportunity in other platforms in Hollywood. Hence, it is also attracting more people to watch and appreciate Netflix. Netflix Original has grown after the release of Orange is the New Black, which exclusively portrays the diversity that is often considered as 'other' (Jenner, 2018), as well as portraying a feminist perspective of women in prison. Netflix further portrays other minority groups in America with various ideologies and beliefs, such as Unorthodox (2020) with its portrayal of ultra-orthodox Hasidic Jewish community in America, and 13 Reasons Why (2017-2020) that tells the heavy subject of suicide and self-harm as the effect of bullying and sexual abuse. Filling in the gap of minority representation, it can be seen how Netflix did make use of the cultural differentiation to portray and attract more audiences. Rather than creating such homogenization and following existing archetypes, it provides a wider variety of content for different identities to invite the feel of representation to the community. This also means that it targets and markets the community to other communities.

As explained by Plothe \& Buck (2019), Netflix is indeed intended to create diverse content as the top priority of their goal. It stresses what Viruet said, "the specificities, cultures, and lived experiences of marginalized groups that don't often get to tell their stories or have them told at all" (as cited in Plothe \& Buck, 2019). They target a larger audience, taking advantage of the gap within the production of mainstream American popular products to which they focus on the minorities that are often hidden behind it. This relates to the characteristics of transnational capitalists that identify themselves as citizens of the world merely for profit and the enhancement of the profit (Sklair, 2007). However, this characteristic only aims to create the cultureideology of consumerism to the audience to make their system fully operate without the boundary of region, country, city, society, or community, but connecting them in a complex global relation (Sklair, 2007). 
Consumer culture in Netflix is promoted by their campaign of "binge-watching." Netflix is widely known for its simultaneous release of all episodes of an entire season only in one time and thus makes the audience to marathon-watch the whole season. The addiction to binge-watch the entire season continuously is not merely an addiction and the consumer culture toward movies, but also a sense of connection to a community or to what is being represented in it (Matrix, 2014). This idea of "binge-watching" is indeed a discerning step to promote more addictive behavior to its consumers along with their attempt to bring the representation of the cultural diversity; further, it also helps to maintain the capital profit to the transnational landscape.

The concept of a diverse culture is being put as the 'main ingredient' of Netflix Originals, therefore, successfully attracts the audience to have their community or identities represented. Thus, they have a connection as the reason for their addiction which appeals to the consumerism the company aims to get as a transnational company. However, this should be acknowledged that the diverse content may be targeted to the United States of America as most of the users are Americans with the amount over 61 million users out of 139 million users as per December 2019 (Moody, 2019). It indicates that the culturally diverse content is still in the American context, carrying the idea that American society is the 'diverse' community. Netflix Originals remains targeting the American society with its American culture, including its lifestyles, values, and point of view as its 'main ingredient.'

Netflix has shown the importance of English, especially to American consumers, with its exclusive stipulation of English dubbing. Netflix fulfills the demand of American consumers who appear to be 'unfamiliar' to non-English movies. While it may be optional, it seems that Netflix is aware of English language as the main concern to American consumers before watching a movie or a series. According to Goldsmith (2019), $85 \%$ of American consumers to Netflix prefers dubbed voice instead of using subtitles to watch The Rain (2018-2020), 78\% to watch Dark (2017-2020), and 72\% to watch Money Heist (2017-) due to their incapability to multitask - to watch and to read subtitles at once. Relating to this, a Korean movie director Bong Joon-Ho once said during his Golden Globe Award 2020 winning speech, "Once you overcome the one inch tall barrier of subtitles, you will be introduced to so many more amazing films.". Bong Joon-Ho's winning speech is directed to the language barrier of English consumers in general, in which they will instantly lose interest in many high quality films simply because of the non-English language spoken in the movie. While Bong Jon-Ho does not speak directly to Netflix users, he represents the concern of nonEnglish producers to reduce the cultural barriers for the 'global audience' to gain more recognition, putting aside the creative flow of the work as a priority.

The dominant power of English language gives the portrayal of the consequences of globalization. From this, the spread of the English product to other countries has two impacts; first, English language with its power symbolizes higher status and higher economic advancement in which producers should concern to; second, the American life carried by English language is becoming more accepted as the global culture, which later leads to more profit to American corporations 
as well. The commodification of American life that leads to consumerism was developed by multinational corporations supported by an imperialist power and engaged in a more complex relationship with the economical, political, and military matter (Rowe, 2010). With the twenty-first century technology, the internet is expected to be the gate to a new cultural movement with unlimited space of communication and exchanges and Rowe saw it as an opportunity for new politics, diminishing hierarchies in modern society, and new cultural practices. Netflix, nevertheless, offers itself as the media for the dominant culture to define its consumers' demands to be the standard of global consumerism, illustrating the importance of English language to be the main requirement as a successful commodity.

Moreover, the consumption of a commodity, as Appadurai (1986) argued, is social, relational, and active, rather than private, atomic, and passive. He further explained that it is largely shaped by the social and economic forces while manipulating the social and economic forces as well. In following Netflix's demand, the local production houses often rely on the hegemonic power of American culture, which is often driven by the strong economic and political power of the United States. The manipulation of the social and economic forces is noticed by the claim of cultural diversity, focusing on the idea of multiculturalism to emphasize, and thus to be consequently demanded. From this perspective, it seems understandable that Netflix's claim as a 'global TV network' is highly welcomed by many communities across the globe, especially the local producers as they get to promote their work globally. Nevertheless, while Netflix itself welcomes the non-American or non-English series, the local production houses must be able to compose their works into certain literary formulas or genres in which the American audiences are familiar in order to be successful and popular.

"Commodities are neither passive nor politically innocent; they are perpetually active in the specific kinds of desires they produce in consumers, and work by means of the social psychologies of commodity fetishism analyzed by Marx in Capital and reification elaborated by Lukács in History and Class Consciousness" (Rowe, 2010)

While it does not fit Rowe's expectation to the new hope of the internet and while Netflix may open the gate for the non-American and non-English series, American still holds power in making meaning and defining meaning including the power in deciding what is meant to be popular. The previously mentioned case of English dubbing shows the continuing cultural power that the American consumers have tried to impose as they are unwilling to hear the original voice spoken in a nonEnglish language. It is an indication of unintentionally understanding the 'Other.' This also gives an interpretation to non-English production houses that English language or American culture involvement is a crucial element in appealing to a global audience. Hence, while the existence of English dubbing gives advantages to Netflix in reaching a wider English speaking audience to consume nonEnglish movies, on the other hand, cultural hegemony of English language is being continued and being maintained into both the non-English speaking audiences and producers. This means that while providing heterogeneity through its content, with its claim of 'cultural diversity' in its series, Netflix also opens a way for the homogenization of language, to which English is highly 
maintained by the demand of its consumers. Of course, it should not be neglected to the fact that Netflix itself helps non-American, even non-Western movies, to reach more audiences. Yet, with the English dubbing replacing the original language, whether the content still appears with their own cultural instruments should be concerned.

\section{Americanizing Europe}

Relating to the previous discussion, it should be acknowledged whether the cultural diversity in Netflix Originals produced in nonAmerican or non-English countries is applied outside the American context. It should be noted that before Netflix, the local television in America has brought the Americans away from foreign cultures. Every non-foreign TV show imported to the American local television is mostly being Americanized. For example, the Japanese cartoon, Pokémon, in American national television has been localized or Americanized to hide its Japaneseness to be widely acceptable to the American audience as the main reason (Iwabuchi, 2002). The success of Pokémon and other non-foreign movies in America, thus, cannot be done without the Americanization of the product.

In this matter, the practice of Americanization is unexceptional to Netflix. Although Aguiar \& Waldfogel (2017) has provided the distribution data showing that Netflix in America does not have the global hegemony to provide 'one-size-fits-all' shows to all destinations, it should be noted that the research only relies on the number. In other words, a straightforward conclusion on the absence of Americanization in Netflix Originals should not be concluded. In fact, as the majority of Netflix users are Americans, and it cannot be denied that Netflix may still play the role of the national or American television, where Americans are their main target and Americanization may be heavily practiced.

This is seen with several non-American shows produced by Netflix. For example, Sex Education (2019-) is produced in UK and casted by British actors and actresses. Yet, McCracken (2020) also saw that there is also a mix of American culture in the characters in which the show looks like an American show spoken with a British accent by British casts. This also goes the same with the Spanish shows Elite (2018-) that many feel like it is set in the United States as well as the characters that live in an American lifestyle. Yet, the creator of Elite, Carlos Montero, stated that the Americanization of the setting and story is unintended. In fact, it is already becoming the Spanish way of life as they are already exposed to that lifestyle from the American shows they have watched long before the production of Elite (Patton, 2019). Both series are produced outside America, casted by nonAmericans, and the original language spoken is non-English as for Elite, yet, the presence of American culture in the works is well acknowledged. It is what makes them more appealing and popular to American audiences or even global audiences.

The difference between both series is that how the Americanization is being put. Americanization in Sex Education functions to make it more appealing to a wider audience, while Elite is not Americanized because the Spanish lifestyle itself is already Americanized in the daily life and thus, Americanization will be included unconsciously. From this, Montero's statement that "we also wanted the themes to be universal and understood in every 
culture" (Weiss, 2019) should be more concerned that the terms "universal" and "understood in every culture" have always been represented by the American culture.

This idea of homogenization is well acknowledged through the Americanization of Netflix Original, which in this discussion can be identified from the European made series; Elite and Sex Education. This may be in line if related to the history of European immigration to America in the previous centuries with their hopes and dreams upon America.

Bourne saw America as "the intellectual background" of a worldwide struggle over the hegemonic nature and prerogatives of the modern European State. Transnationalism for him then describes the process by which an imagined America would ideally provide a national political framework for a culture of international identities. (Mihăilă, 2011)

The offer to an escapism of European chaos became a big advantage for America to value personal freedom, to make a great distinction from European countries and culture. As the idea of 'imagined America' is to pursue personal freedom and a better life, international identities were identified based on those hopes from the immigrants coming to America. This is where international identity, in this cultural context, is identified as American identity to represent the whole world and consider it as 'universal' and 'understandable in every culture.' Hence, Netflix's claim as a 'global TV network' took its place to represent the world as well as to control the world in how to see and how to be seen through its consumers' demand. In this matter, the contemporary hegemonic power does not lie in the European countries anymore but in America itself.
It must be quite odd to consider Americanization in Europe as a form of cultural imperialism due to the colonization and imperialism predominantly done by the European itself. However, with the previous discussion, such cultural imperialism to Europe does exist with its resistance and rejection as well. The Americanization found its way to Europe after World War II through advertisements of American mass culture, including Hollywood movies. It caused critical debates on whether Europe should reject the American culture or adapt it. The American advertisement glorifying the fantasy of American life consists of the unbounded space, the freedom from European limits, the personal success, and even erotic gratification through culture industry of Hollywood (Stephan, 2006; Holton, 2000). The idea of American individual freedom and American dream, later, affected the contemporary European culture to be as open as America. Therefore, looking back to Elite and Sex Education, it is reasonable to see the European-made Netflix Originals that do not have significant differences if compared to the American ones. As much as homogenization becomes the cultural consequence of the worldwide spread of multinational companies in the global market (Holton, 2000), Netflix Original series produced by European production houses appears to be another cultural result of Americanization despite the previous European imperial power.

In one unique case, this is also seen in another Netflix series entitled Bridgerton (2020), with its historical setting that took place in the $19^{\text {th }}$ century of England. With the claim of cultural diversity of Netflix, the series portrays people of color as a member of a respectful family during Queen Charlotte regency, which may be historically impossible. 
The portrayal of diversity in Bridgerton purely to maintain the cultural diversity image Netflix has, as a market and a trend to the 21 st century demand. Beers Betsy, the producers of the series itself is American; with her consciousness to produce the England historical series, she said, "We try to imagine history and the world in the way we wanted to see it." (Lenker, 2020). This, once again, offers an escapism from the European world in which it tries to satisfy the modern audience, predominantly the culturally diverse Americans. From this, it is also concerning that such portrayal of $19^{\text {th }}$ century England itself may be shifted through the influence of American perspective rather than the European themselves - confirming the American cultural power in shaping knowledge. This is where cultural imperialism in the form of Americanization needs to be taken seriously as it is able to modify and fantasize about other cultures, creating such different meanings without any consent from related countries.

This pretty much explains how Netflix, as the global company is also an American transnational capitalist. The Americanization found in Netflix Originals is heavily influenced by the American industry that has previously introduced the American culture to the global society even before Netflix does. Thus it only depends on the consumerism of the audience to demand their specific preference of a story concept to binge-watch. From that, it can be concluded that the Americanization has been dominating the European producers and Netflix only continues the legacy in spreading more Americanization to the global audience. Therefore, Aguiar \& Waldfogel's (2017) statement can be agreed as well that Netflix's goal to produce and distribute the US programs as the global strategy for its global expansion will bring bad news to the local producers whose works have not been Americanized yet.

\section{Americanization in Asia}

The discourse of transnationalism, as Mihăilă (2011) further explained, does not put its emphasis on the homogenization of American culture as international culture but also on the interaction between local and global culture which later produces heterogeneity. Borrowing the term of polarization, we may come to the categories of Western and non-Western as Edward Said has introduced through his influential work, Orientalism. Polarization, as Holton (2000) explained, concerns the global cultures divided into two powerful categories, in which it is connected through history and power. The category of Western and non-Western (the West and the East) may be identified by distinguishing its cultural portrayal. It is quite apparent to acknowledge how the production of Netflix and the cultural division of Netflix series are more visible for Asia, taking an example of Netflix series categorization for specific countries such as Chinese, Korean, and Southeast Asian. At the same time, Europe only has British - putting other European series mixed with American series.

This is where heterogenization of Netflix is most likely to occur under the two divisions of polarization. While Americanization successfully 'colonize' the European production houses, the Asian production houses managed to be different from the Western production by maintaining their local culture. From this, Netflix Originals produced by Asian production houses appear to be culturally distinct from the European production. Aside from the significantly different language and place setting, portrayal 
such as food, cultural behavior and manner, and fundamentally cultural values employed by Asian communities are very much apparent in the movies or series. In this context, the term 'local' for Asian culture is exposed by Netflix to the global audience and the form of interaction between local and global seems to be more obvious than the European products. Indeed, this argument may be obvious as Asian cultures themselves is more diverse than the European cultures and that historical European movies or series are as interesting as historical Asian ones. However, knowing that the Asian produced content needs a very strong interaction with the global culture in order to be attractive in the eyes of the global consumers - the Westerners and the Americans - and to exist in the global market, it should not be blatantly ignored that there is an effort of Asian production houses in collaborating the local culture and global culture at once.

The global culture appearing in Asian products may be easily identified through the rapid increase of Korean drama on Netflix. Ju (2019) has conducted a research on American viewer's reception of K-drama on Netflix. While the viewers may have a sense of connection and representation to Asian culture, predominantly the Asian-American audience, there is also the conventional archetype employed by the drama, which is romance. Ju saw the use of Western romance archetype of 'a rich man loving poor woman' to help to gain wider audience and bigger success among the transnational fans. Taking the example of rising popularity for romance K-drama, it may be true that other Western literary archetypes are also employed by the Asian producers to be accepted and easily consumed by the consumers. However, there are also several things that may be different from the Western archetype, such as the portrayal of male characters to be more femininely and gently handsome instead of using Western's physically strong and powerful figure of a man.

The popularity of Korean drama is rapidly growing from year to year to the global consumers, including before Netflix provides the drama on their platform. There is, in fact, a reasonable cause to the popularity of Korean drama to the global consumers, where Americanization is deeply embedded in contemporary South Korean life due to the close relationship between the United States and South Korea after World War II and after the Korean Financial Crisis in 1997. Both globalization and Americanization has affected many South Korean's life, such as emphasizing the importance of English in education. English is becoming important to seek the economic advancement to which many transnational companies in South Korea require them to be able to speak English. This is where the English learning also means to the understanding of American cultural values (Park, 2009). The American values, therefore, are deeply embedded in the lifestyle of the South Koreans, especially to the youths on which it often focuses to. This also means that the wide popularity of K-drama itself is elevated by the existence of American values, or even American lifestyle to be the 'foundation' of the drama, which global consumers can easily enjoy.

This application of Americanization shows the best form of cultural imperialism. Cultural imperialism done by Netflix is identified by the unequal flow of culture from the dominant culture to the dominated, in which this American culture is strongly associated with the economic and political 
hegemony to spread the American consumerist ideology (Iwabuchi, 2002). This also shows the unequal relationship of America as the West and the others, where cultural domination of America and the exploitation of local culture by Americans happen. In the perspective of transnational culture, as Iwabuchi (2002) further explained about what Stuart Hall has termed as 'global mass culture' to characterize the global spread of culture, it seems that the global capitalist does want to absorb the cultural differences from all cultures within the concept of American to operate and dominate the world. This concept of hybridity of the local culture to the dominating culture implies how the local culture cannot be fully recognized or gain an influencing power without the help of Americanization. This is also in line with what Sklair has listed in the discussion of transnational company in the globalization, homogenization, and hybridization which is produced by globalization through transnational company is oriented on the capitalism merely for profit, while at the same time may destroy or sustain a certain culture as the 'side effect.' Thus, the participation of Netflix as the 'global TV network' itself fully plays the role of cultural imperiality; they control over the foreign market, foreign investment, and foreign participation as the main resource to the company, as well as creating a new market for them (Ritzer, 2011). What is being stressed in the controlling of the foreign culture's participation in the Netflix products is that the use of Americanization gives the producers more options, whether to put the foreign culture in the product or to modify the foreign culture to make it more appealing to the audiences.

Rather than imposing a totally foreign cultural product, they demonstrate intent in satisfying audiences with products adapted to their needs and demands. Rather than classic imperialism, we find asymmetrical interdependence. Within a world capitalist system, we find national and regional media firms gaining considerable market power against the giant global firms that entered the local markets via satellite and cable television technologies. (Straubhaar \& Duarte, 2005)

Lastly, looking back to the local television within globalization, they still had the power to attract local audiences with local content in the previous decades. In such cases, local production houses focus on understanding the deep cultural demands of their local audience and making global television to be 'unsuccessful' in several places. However, as much as Straubhaar \& Duarte saw this phenomenon before the rise of SVOD in the global market, there seems to be a change in the interest of local production houses that they do not entirely target local audiences any longer. The availability of locally produced series in Netflix will increase their work to be visible, and thus, to be more profitable. This causes local producers to turn their face to the global audience rather than the local audience, collaborating with the American archetype in favor of the global audience's demand. Again, Aguiar \& Waldfogel's (2017) fear of Netflix's power over the local producers that have not been Americanized yet seems to realize as technology advancement grows along with Netflix as a 'global TV network.'

\section{CONCLUSION}

As it has been long discussed, the questions proposed in the introduction are answered in a more complex way. Netflix, as a global company as well as a transnational capitalist, successfully put the cultural diversity as their top priority of their products. However, the portrayal of cultural diversity 
emphasizes American multiculturalism and highlights the inauthenticity of the nonAmerican culture. The Americanization of non-American series indicates cultural power domination. Americanization takes place because of two factors. First, it is targeted to the American audience as the largest group of Netflix customers. Second, it makes the content to be 'universally' accepted worldwide as the world is already more familiar with the American culture than with any other culture. With that said, cultural diversity, as Netflix shows, is a practice of cultural imperialism as it is in favor of the American audience in its attempts to attract more cultural groups from all over the world for profit. The claim of a 'global TV network' itself does not leave the American cultural power; instead, they are taking advantage of the cultural power to retain the existing audiences and fascinate more audiences.

\section{REFERENCES}

Aguiar, L. and Waldfogel, J. (2017). Netflix: global hegemon or facilitator of frictionless digital trade?. Journal of Cultural Economics, 42(3), 419-445.

Appadurai, A. (1986). Introduction: Commodities and the politics of value. The social life of things: commodities in cultural perspective. Cambridge University Press.

CBS News. (2016). Suddenly, Netflix is a "global tv network". Retrieved May 15, 2020 from

https://www.cbsnews.com/news/suddenl y-netflix-is-a-global-tv-network/

Goldsmith, J. (2019). Netflix wants to make its dubbed foreign shows less dubby. Retrieved February 1, 2021 from https://www.nytimes.com/2019/07/19/ar ts/television/netflix-money-heist.html

Holton, R. (2000). Globalization's cultural consequences. The ANNALS of the
As much as Appadurai (1986) sees demand as "the economic expression of the political logic of consumption," this idea enables a more visible dominant power of American cultural products as well as the American capitalist global system. Netflix is an actor that plays a significant role in maintaining the economic and political power of the United States through the cultural power of Americanization. The dependency of local producers in relying on Netflix platform as a way to reach global audience, even with the use of Americanization in their works for global audience's satisfaction, confirms the cultural power of America in its ability to bring economic advancement to other countries, which later also bring political advancement and power to the United States.

American academy of political and social science, $570(1)$, 140-152.

\subsection{7/0002716200570001011.}

Iwabuchi, K. (2002) Taking "Japanization" seriously. Recentering Globalization, pp. 23-50.

Jenner, M. (2018). Netflix and the re-invention of television. Palgrave Macmillan.

Ju, H. (2019). Korean TV drama viewership on Netflix: Transcultural affection, romance, and identities. Journal of international and intercultural communication, 13(1), 32-48. 10.1080/17513057.2019.1606269.

Laemmerhirt, I. (2013). Embracing differences: Transnational cultural flows between Japan and The United States. Transcript Verlag.

Matrix, S. (2014). The Netflix effect: Teens, binge watching, and on-demand digital media trends. Jeunesse: Young People, Texts, Cultures, 6(1), 119-138. 
Maureen Lee, L. (2020). How 'Bridgerton' is poised to revolutionize romance on television. Retrieved February 2, 2021 from https://ew.com/tv/bridgertonpoised-revolutionize-romancetelevision/

McCracken, G. (2020). Is Netflix's Sex Education US/UK mashup the future of TV?. Retrieved May 15, 2020 from https://www.theguardian.com/comment isfree/2020/jan/29/netflix-sex-educationus-uk-british-american

Mihăilă, Rodica. (2011). Cultural translation and the discourse of transnationalism in American studies. Journal of Transnational American Studies, 3(1).

Moody, R., (2019). Netflix subscribers and revenue by country. Retrieved May 15, 2020 from

\section{https://www.comparitech.com/tv-} streaming/netflix-subscribers/

Park, Seong Won. (2009). The present and future of Americanization in South Korea. Journal of futures studies, 14(1), 51 - 66.

Patton, R., (2019). Why 'Elite' has an americanized feel, even though it's filmed in Spain. Retrieved May 15, 2020 from https://www.bustle.com/p/where-iselite-filmed-theres-a-reason-the-showhas-american-feel-18739954

Plothe, T. and Buck, A. (2019). Netflix at the Nexus. Peter Lang Inc., International Academic Publishers.

Ritzer, G. (2011). Globalization: The Essentials. John Willey \& Sons Ltd.

Rossi, I. ed. (2007). Frontiers of globalization research: Theoretical and methodological approaches. Springer.

Rowe, J. (2010). Culture, US Imperialism, and globalization. A concise companion to American studies. Blackwell Publishing.

Sklair, L. (2007). A Transnational Framework for Theory and Research in the Study of Globalization. In I. Rossi (ed.), Frontiers of globalization research: Theoretical and methodological approaches. Springer.

Stephan, A. (2006). The Americanization of Europe. Berghahn.

Straubhaar, Joseph D. \& Duarte, Luiz G. (2005). Adapting US transnational television channels to a complex world: From cultural imperialism to localization to hybridization. In Chalaby (ed.), Transnational television worldwide: Towards a new media order. IB Tauris.

Weiss, N., (2019). Elite creators are Dawson's creek fans, but that doesn't mean they intentionally Americanized their Spanish series. Retrieved May 15, 2020 from https://www.primetimer.com/item/Elite -creators-are-Dawsons-Creek-fans-butthat-doesnt-mean-they-intentionallyAmericanized-their-Spanish-series$\underline{\text { NXSAm9 }}$ 